\title{
Giant Bamboo Fiber Reinforced Epoxy Composite in Multilayered Ballistic Armor
}

\author{
Renato Batista da Cruz ${ }^{a}$, Edio Pereira Lima Junior ${ }^{a}$, \\ Sergio Neves Monteiro ${ }^{a *}$, Luis Henrique Leme Louro ${ }^{a}$ \\ ${ }^{a}$ Department of Materials Science, Military Institute of Engineering - IME, \\ Praça General Tibúrcio, 80, Praia Vermelha, Urca, CEP 22290-270, Rio de Janeiro, RJ, Brazil
}

Received: November 7, 2014; Revised: April 28, 2015

\begin{abstract}
The ballistic performance of a multilayered armor with a front ceramic tile backed by a plate of giant bamboo fiber reinforced epoxy composite was assessed. The ceramic layer spalls the projectile, while the bamboo composite dissipates the remaining energy. Ballistic tests were performed with high velocity ammunition and the projectile penetration was evaluated by the intrusion depth in a clay witness. The average depth value of near $18 \mathrm{~mm}$ was found well below the limit specified by the NIJ standard of $44 \mathrm{~mm}$ and better than that for aramid fabric composite, about $22 \mathrm{~mm}$, with the same thickness of the giant bamboo composite. The giant bamboo composite acts as an efficient barrier for the fragments originated from the ceramic brittle rupture. For practical application in portable armor for personal protection, the layer of giant bamboo composite presents not only a superior ballistic performance but also lightness and economical advantages over the conventional aramid fabric.
\end{abstract}

Keywords: ballistic test, multilayered armor, bamboo fiber composite, bullet penetration analysis

\section{Introduction}

Personal protection against high velocity $(>700 \mathrm{~m} / \mathrm{s})$ ammunition, such as the $7.62 \times 51 \mathrm{~mm}$ caliber bullet, requires a light shielding based on multilayered armor system (MAS) with high impact absorption and resistance to projectile penetration $^{1}$. MAS are usually composed of a harder front ceramic tile with the ability to deform and erode/fracture the projectile ${ }^{2-5}$. Owing to this ceramic frontal layer, a great deal of the projectile energy is dissipated by means of its fragmentation involving mechanisms of nucleation, growth, coalescence and propagation of micro cracks $^{6}$. A second MAS layer backing the ceramic is selected as a lighter composite material, which reduces the impact energy by absorbing part of the blast of fragments from either projectile or ceramic ${ }^{7}$. For this second layer, glass fiber composites have originally been investigated ${ }^{8}$. Aramid fabric such as Kevlar ${ }^{\mathrm{TM}}$ and Twaron $^{\mathrm{TM}}{ }^{[9]}$ as well as ultra high molecular polyethylene (UHMPE) fiber such as Spectra ${ }^{\mathrm{TM}}$ and Dyneema ${ }^{\mathrm{TM}}[10,11]$ are today preferred for the lightweight body armor second layer MAS composites. A MAS system may also include a third metallic layer acting as a final barrier, which restricts the penetration of the projectile or its fragments beyond the maximum standard indentation or intrusion depth of $44 \mathrm{~mm}$, which causes serious injure to a personal body. In some cases, a spall shield is attached on the front of the armor to avoid flight way ceramic fragments ${ }^{4,5}$.

As the lighter component of a body armor vest, the intermediate composite layer, usually aramid or UHMPE, is not only intended to provide comfort and mobility to the wearer but also to improve the absorption efficiency of the projectile impact. Lower shock impedance composite like the Kevlar ${ }^{\mathrm{TM}}$ standing behind the front interface will cause

*e-mail: snevesmonteiro@gmail.com the proceeding compressive wave to be comparatively lower in transmitted energy. Since the shock impedance is directly related to the material's density, a greater ballistic impact energy reduction should be provided by a comparatively lighter composite backing the ceramic tile ${ }^{12-15}$. The replacement of the aramid fabric by a lower density fiber reinforced composite would be an alternative to improve the impact absorption. A possible candidate might be a lighter polymer composite reinforced with natural fibers obtained from plants, also known as lignocellulosic fibers. In addition to a lower density than aramid fabric, these natural fiber composites are less expensive and regarded as environmentally friendly. Indeed, lignocellulosic fibers are renewable, degradable, recyclable and considered "neutral" with respect $\mathrm{CO}_{2}$ emissions, responsible for the global warming. With about 55\% carbon, they emit a similar amount of $\mathrm{CO}_{2}$ after degradation as absorbed during cultivation. Furthermore, they are not as energy intensive as synthetic fibers such as glass, carbon and aramid fibers during processing ${ }^{16}$. In the past decades, a great number of works has been dedicated to polymer composites reinforced with lignocellulosic fibers. Several papers reviewed these composites ${ }^{17-29}$ that are being applied in industrial sectors, particularly the automotive industry ${ }^{30,31}$.

Among the most engineering applied plants, the well known bamboo, with rigid culms, has potential to be used as ballistic resistant material. As any plant, bamboo is basically formed by cellulose microfibrils embedded in hemicellulose and lignin ${ }^{16-29}$. The bamboo culm has a unique microstructure composed of stiff sclerenchyma cells, extending lengthwise as cellulose microfibrils around vessels used to transport water and nutrients. Less dense parenchyma cells surround each bundle of microfibrils and 
vessels, as a soft foam-like matrix ${ }^{32}$. Owing to its relatively low density, $1.03-1.21 \mathrm{~g} / \mathrm{cm}^{3}$, and convenient tensile strength, 106-204 $\mathrm{MPa}^{[12]}$ the bamboo culm and extracted fiber have been, since long time, used in engineering applications. As an abundant natural resource in tropical and temperate regions, especially Asia and Latin America, bamboo is substituting plastics in civil construction, furniture and lightweight parts of vehicles ${ }^{33,34}$. However, the cylindrical shaped culm limits some direct uses of the bamboo and motivated investigations on bamboo fiber as reinforcement of polymer composites ${ }^{33-44}$. Actually, a bamboo fiber corresponds to many microfibrils (sclerenchyma cells) and vessels, known as vascular bundle, which may be extracted from the parenchyma cell matrix by longitudinal slicing procedure ${ }^{45}$. A stronger specie of giant bamboo (Dendrocalamus giganteous Munro) has recently attracted attention for its relevant properties ${ }^{46-48}$, including the impact resistance ${ }^{49}$.

A systematic investigation on the ballistic properties of natural fiber reinforced polymer composites has already been conducted by Wambua et al. ${ }^{50}$. Relevant information on the ballistic impact velocity and energy related to natural fiber composites was presented by the authors but it was not their scope to assess the performance of natural fiber composites as armor for personal protection.

In the present work, the ballistic performance of multilayered armors composed of a front ceramic, an intermediate composite and aluminum layers was investigated in terms of the intrusions caused by the projectile into a clay witness simulating a personal body. Ballistic tests were conducted in MAS's with a front $\mathrm{Al}_{2} \mathrm{O}_{3}$ ceramic tile. As the following intermediate layer, lighter giant bamboo fiber reinforced epoxy composite plates were compared to plain epoxy plates and aramid fiber plies, all with the same thickness.

\section{Material and Methods}

The multilayered armor system (MAS) arrangement used in this investigation was the following: the front layer was a $15 \mathrm{~mm}$ thick hexagonal tile with $31 \mathrm{~mm}$ of side dimension made of $4 \mathrm{wt} \% \mathrm{Nb}_{2} \mathrm{O}_{5}$ doped $\mathrm{Al}_{2} \mathrm{O}_{3}$ brittle ceramic. The ceramic tile was fabricated by sintering $\mathrm{Al}_{2} \mathrm{O}_{3}$ powder supplied by
Treibacher Schleifmittel as commercial purity mixed with $\mathrm{Nb}_{2} \mathrm{O}_{5}$ powder supplied by CBMM as $99 \%$ pro-analysis. Sintering was conducted at $1,400{ }^{\circ} \mathrm{C}$ for 3 hour under air in the Ceramic Laboratory of the Military Institute of Engineering (IME), city of Rio de Janeiro, Brazil.

The intermediate layer, with $10 \mathrm{~mm}$ in thickness and square sides with $150 \mathrm{~mm}$, was either: (i) 16 plies of aramid fabric, or (ii) a plate of $30 \mathrm{vol} \%$ of continuous and aligned giant bamboo fibers reinforced epoxy matrix composite (giant bamboo composite for short), or (iii) a plate of plain epoxy. The aramid fabric plies were supplied by the LFJ Blindagem Com. Serv. S.A., as compressed pieces with very little, less than $1 \%$, epoxy adhesive, as indicated by the supplier. Giant bamboo culms were kindly donated by Prof. Khosrow Ghavami from the plantation existing at the Catholic University of Rio de Janeiro (PUC-Rio). At IME, giant bamboo fibers were smoothly sliced from the culm, starting with a razor and following the continuous tendency to longitudinally separate neighbors vascular bundles. These fibers were obtained with a length corresponding to the extension of the culm, around $15 \mathrm{~cm}$, but with their naturally different diameters. The diameters, average of width and thickness, measured by profile projector, were found to vary from 100 to $700 \mu \mathrm{m}$ with an average of $400 \mu \mathrm{m}^{46}$. Figure 1 illustrates: (a) the microstructure of typical thin bamboo fiber with microfibrils and few residual parenchyma cells and (b) the fracture tip of a thicker fiber displaying vascular bundle. No chemical treatment was applied to the individual fibers. Bamboo fibers were dried at $60^{\circ} \mathrm{C}$ in a laboratory stove for 2 hours and aligned with the correct amount of $30 \mathrm{vol} \%$ inside a steel mold. An initially fluid diglycidyl ether of the bisphenol-A (DGEBA) epoxy resin, mixed with a phr 13 stoichiometric fraction of trietylene tetramine (TETA) as hardener, was poured onto the mold. A pressure of $5 \mathrm{MPa}$ was applied and the composite plate cured for 24 hours.

Figure 2 shows: (a) the epoxy composite production scheme with 5 layers of aligned fibers and (b) a finished composite plate. In a similar procedure, plain DGEBA/TETA epoxy plates were also fabricated. The back end-layer was a $150 \mathrm{~mm} \times 150 \mathrm{~mm} 5052 \mathrm{H} 34$ aluminum alloy (Al) sheet

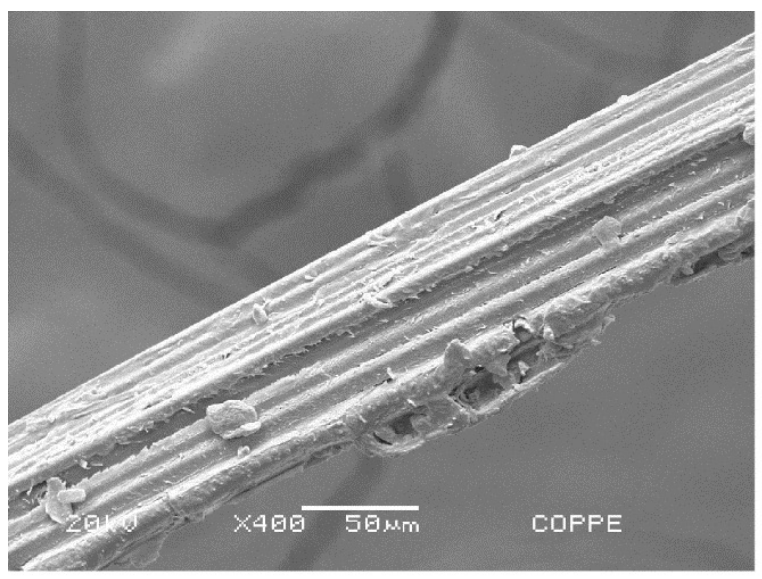

(a)

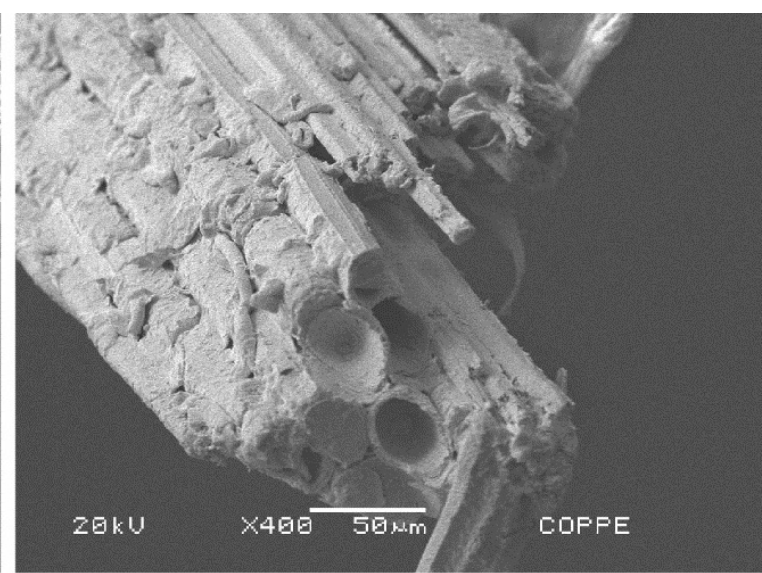

(b)

Figure 1. The giant bamboo: (a) SEM of a thin bamboo fiber and (b) fracture tip of a thicker bamboo fiber. Source: authors. 
with $5 \mathrm{~mm}$ in thickness. These layers were bonded together with commercial Sikaflex ${ }^{\mathrm{TM}}$ glue from Sika Co.

In direct contact with the Al sheet back end-layer, a block of clay witness simulated a personal body protected by the MAS. The clay witness was warmed to $40^{\circ} \mathrm{C}$ according to specifications and compressed to avoid air bubbles. The clay was commercially supplied by Americanas Express. The depth of intrusion in the clay duplicates the plastic deformation imposed by the fragments, generated from the projectile impact, on the $\mathrm{Al}$ sheet. The corresponding depth, Figure 3, was measured with a special Mitutoyo caliper with an accuracy of $0.01 \mathrm{~mm}$. A minimum of 10 measurements

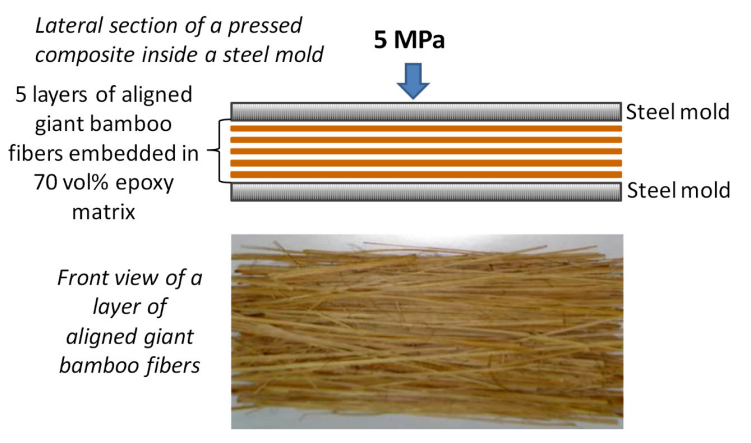

(a)

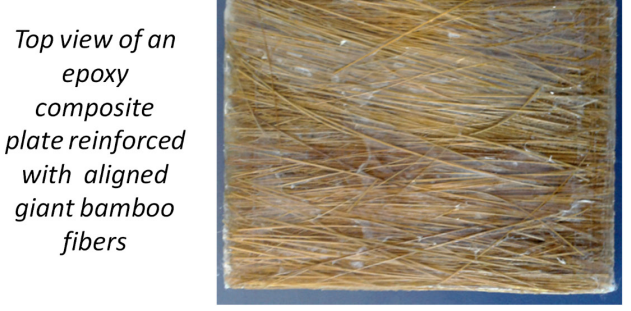

(b)

Figure 2. Giant bamboo fiber composite: (a) schematic production and (b) epoxy composite plate. Source: authors.

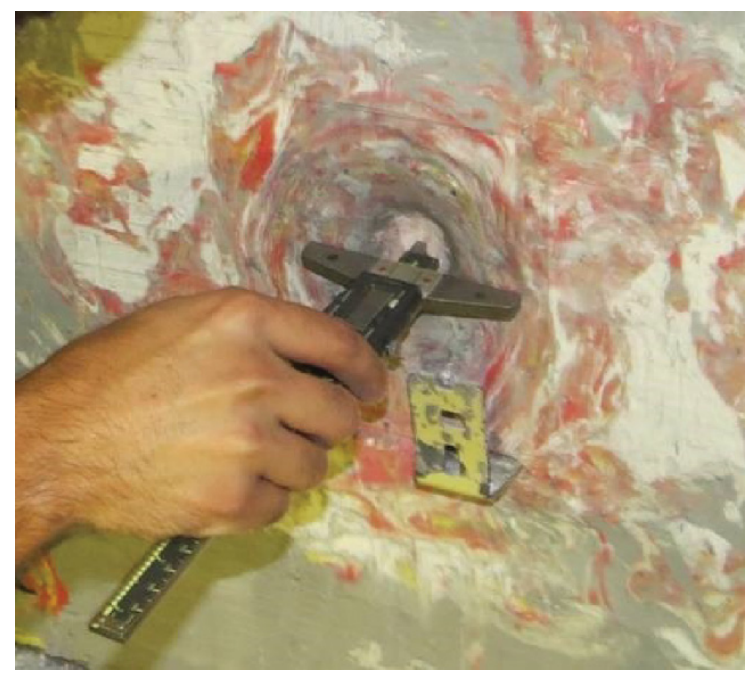

Figure 3. Measurement of the depth in the clay witness caused by the projectile impact. Source: authors. was performed for each depth of intrusion and the values were analyzed by means of the Weibull statistic method. This provided confidence indexes $\mathrm{R}^{2}$ greater than 0.9 . The microstructure of giant bamboo fibers and fracture details of the composites and aramid fabric after ballistic tests were observed by scanning electron microscopy (SEM) in a 6460 LV JEOL and a Quanta FEG 250 FEI microscopes.

Figure 4 illustrates the actual front view of a clamped MAS ready to be ballistic tested. Ballistic tests were carried out at the Brazilian Army shooting range facility, CAEX, in the Marambaia peninsula, Rio de Janeiro. All tests, 10 for each type of MAS, were performed according to the NIJ 0101.03 and NIJ 0101.04 standards using $7.62 \times 51 \mathrm{~mm}$ NATO military ammunition, with $9.7 \mathrm{~g}$ copper projectile shot from a gun barrel.

\section{Results and Discussion}

Table 1 presents the average depth of intrusions measured in the clay witness for the different MAS target investigated. In this table, some points are worth discussing. The three materials tested as the intermediate layer that follows the front ceramic layer showed corresponding depth below the NIJ standard 0101.06 limit of $44 \mathrm{~mm}$ for serious blunt trauma. Indeed, all ballistic tests conducted in the MAS's failed to

Table 1. Average depth of intrusion in the clay witness backing different multilayered armors.

\begin{tabular}{cc}
\hline Intermediate Material Layer & Indentation $(\mathbf{m m})$ \\
\hline Aramid fabric plies & $22.67 \pm 2.79$ \\
Epoxy composite & $17.58 \pm 1.88$ \\
$\quad$ reinforced with & \\
$30 \%$ giant bamboo fiber & $19.84 \pm 1.09$ \\
Plain epoxy plate & \\
\hline
\end{tabular}

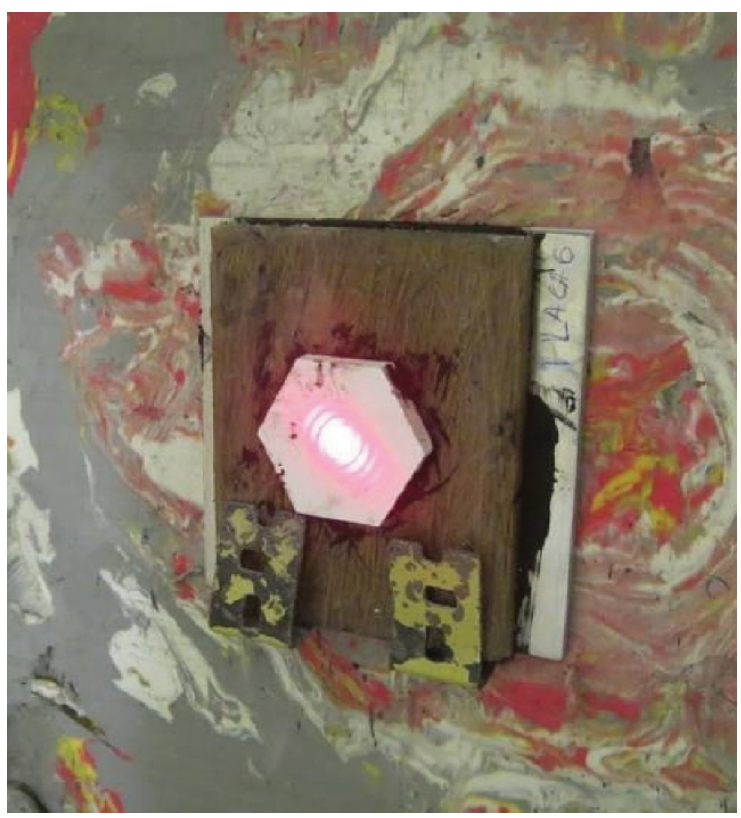

Figure 4. Actual view of a clamped MAS with giant bamboo composite plate ready to be ballistic tested. Laser beam focusing in the center of the ceramic plate as sight. Source: authors. 
perforate the target. Consequently, the projectile was always stopped and its kinetic energy was dissipated inside the multilayered armor in association with the depth in the clay witness, as shown in Figure 3. In Table 1, the aramid fabric with $22.67 \mathrm{~mm}$ displays the greatest depth in comparison to both the giant bamboo composite with $17.58 \mathrm{~mm}$ and the plain epoxy with $19.84 \mathrm{~mm}$.

Within the interval of Weibull precision, the bamboo fiber composite has a statistically smaller depth than the aramid fabric but similar to the plain epoxy. The reason for this behavior can be attributed to a recently proposed mechanism of ballistic fragments captured by the aramid fabric layer ${ }^{51}$. The giant bamboo composite depth corresponds to a $22 \%$ better ballistic performance, as compared to the aramid fiber. This is a surprising result since the aramid $(\sim 4,000 \mathrm{MPa})$ is much stronger than the epoxy $(\sim 90 \mathrm{MPa})$ and the giant bamboo fiber $(\sim 200 \mathrm{MPa})$. However, the capture of fragments and the impact energy absorption by the giant bamboo fiber reinforced composite, Figure $2 b$, are apparently more effective mechanism than the corresponding in the aramid fabric ${ }^{51}$. Indeed, Figure 5 shows that the composite (a) displays more fragments and decohesion than the aramid fiber (b). Furthermore, the giant bamboo composite is significantly lighter and less expensive than the aramid fabric. These might be considered as practical advantages in favor of giant bamboo composites over aramid fabric plies.

For quantitative discussion, Table 2 presents the parameters that allow a calculation of the weight and cost of each different MAS investigated. Values for the parameters used in this table were given by the suppliers or obtained from the literature ${ }^{52}$. Although the actual $\mathrm{Al}_{2} \mathrm{O}_{3}$ ceramic used in the armor was a smaller hexagonal tile, for practical condition, its calculated face area was considered covering the whole $15 \mathrm{~cm} \times 15 \mathrm{~cm}$ of the target. In Table 2, it should be noticed that the MAS with giant bamboo composite represents more than $4 \%$ of decrease in total weight of the armor. In addition, it also corresponds to more than $31 \%$ of decrease in total cost. In a real situation, the approximately $22 \%$ superior ballistic performance of the giant bamboo composite, Table 1, which is within the NIJ limits, together with $5 \%$ lightness and $31 \%$ economical advantages, Table 2 , favor its substitution for the aramid fiber in a MAS for personal protection.

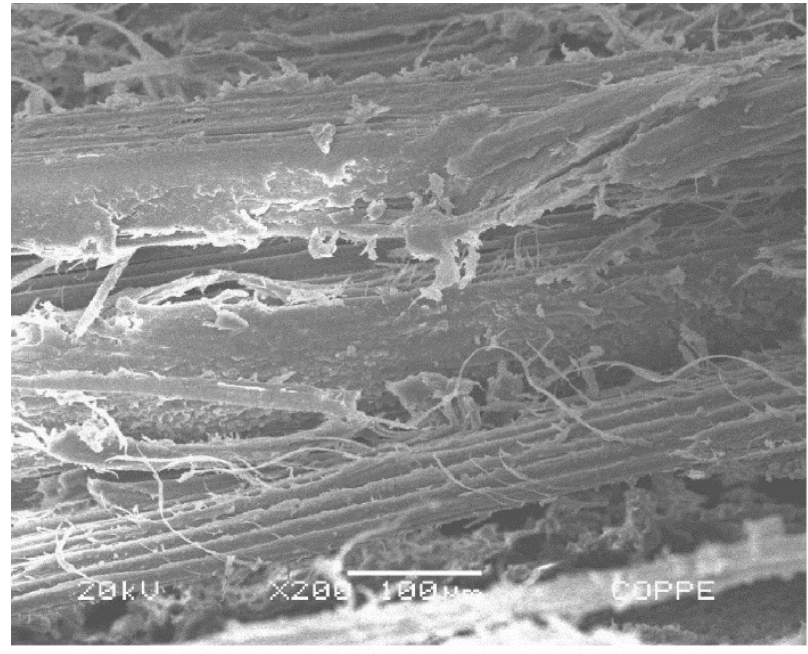

(a)

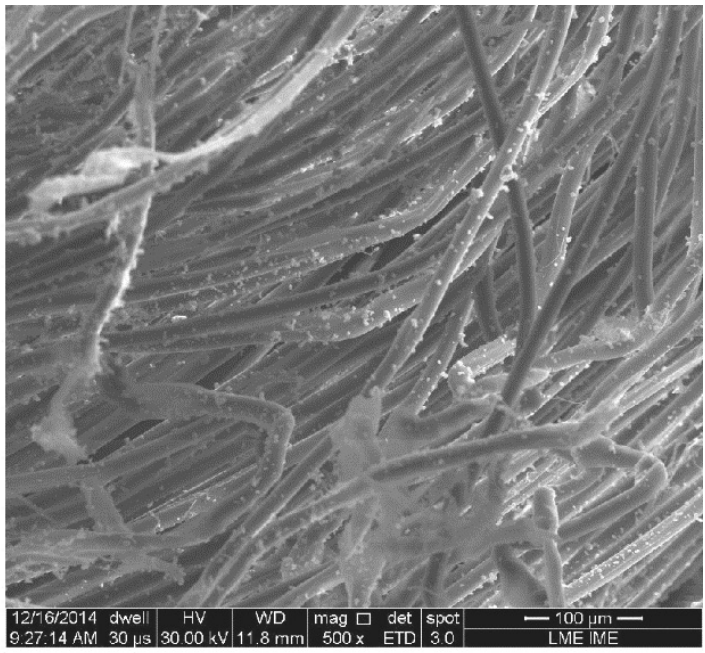

(b)

Figure 5. SEM of ballistic fracture of (a) giant bamboo fiber reinforced epoxy composite and (b) aramid fabric in a MAS. Source: authors.

Table 2. Evaluation $\mathrm{f}$ weight and cost of the different multilayered armors.

\begin{tabular}{|c|c|c|c|c|c|c|}
\hline $\begin{array}{l}\text { Armor } \\
\text { component }\end{array}$ & $\begin{array}{l}\text { Volume } \\
\left(\mathrm{cm}^{3}\right)\end{array}$ & $\begin{array}{l}\text { Density } \\
\left(\mathrm{g} / \mathrm{cm}^{3}\right)\end{array}$ & & $\begin{array}{l}\text { Weight } \\
\text { (kgf) }\end{array}$ & $\begin{array}{l}\text { Price per kg } \\
\text { (US dollars) }\end{array}$ & $\begin{array}{l}\text { Component cost } \\
\text { (US dollars) }\end{array}$ \\
\hline $\begin{array}{l}\mathrm{Al}_{2} \mathrm{O}_{3} \text { ceramic } \\
\text { tile }\end{array}$ & 337.5 & 3.72 & & 1.256 & 33.00 & 41.43 \\
\hline $\begin{array}{l}\text { Aramid fabric } \\
\text { plies }\end{array}$ & 225 & 1.44 & & 0.324 & 63.60 & 20.61 \\
\hline $\begin{array}{l}\text { Giant bamboo } \\
\text { composite plate }\end{array}$ & 225 & 1.09 & & $\begin{array}{c}0.245 \\
\text { Epoxy } 2.80 \\
(70 \%)\end{array}$ & $\begin{array}{l}\text { Fiber } 0.74 \\
\quad(30 \%)\end{array}$ & 0.53 \\
\hline $\begin{array}{l}6061 \text { aluminum } \\
\text { sheet }\end{array}$ & 112.5 & 2.70 & & 0.304 & 8.50 & 2.58 \\
\hline \multicolumn{2}{|c|}{ Total weight with aramid fabric (kgf) } & \multicolumn{2}{|r|}{1.884} & \multicolumn{2}{|r|}{ Total cost with aramid fabric } & 64.62 \\
\hline \multicolumn{2}{|c|}{$\begin{array}{l}\text { Total weight with giant bamboo fiber } \\
\text { composite (kgf) }\end{array}$} & \multicolumn{2}{|r|}{1.805} & \multicolumn{2}{|r|}{$\begin{array}{l}\text { Total cost with giant bamboo fiber } \\
\text { composite }\end{array}$} & 44.51 \\
\hline \multicolumn{2}{|c|}{$\%$ of decrease } & \multicolumn{2}{|r|}{4.20} & \multicolumn{2}{|r|}{$\%$ of decrease } & 31.1 \\
\hline
\end{tabular}


These comments are restricted to the $7.62 \times 51 \mathrm{~mm}$ NATO ammunition used in the present ballistic tests.

\section{Conclusions}

- An epoxy matrix composite reinforced with giant bamboo fiber in substitution for conventional aramid fabric plies, with same total thickness, in a multilayered armor for personal protections attended the NIJ trauma limit after ballistic tests with high velocity $7.62 \times 51 \mathrm{~mm}$ ammunition.

- The ballistic performance of the giant bamboo composite is $22 \%$ superior (lower depth of intrusion in clay

\section{References}

1. Abrate S. Ballistic impact on composite structures. 1st ed. Cambridge: Cambridge University Press; 1998. p. 215-220.

2. Medvedovski E. Lightweight ceramic composite armor system. Advances in Applied Ceramics. 2006; 105(5):241-245. http:// dx.doi.org/10.1179/174367606X113537.

3. Shokrieh MM and Javadpour GH. Penetration analysis of a projectile in ceramic composite armor. Composite Structures. 2008; 82(2):269-276. http://dx.doi.org/10.1016/j. compstruct.2007.01.023.

4. Medvedovski E. Ballistic performance of armor ceramics: Influence of design and structure - part I. Ceramics International. 2010: 36(7): 2103-2115

5. Medvedovski E. Ballistic performance of armor ceramics: Influence of design and structure - part II. Ceramics International. 2010: 36(7): 2117-2127.

6. Louro LHL and Meyers MA. Effect of stress state and microstructural parameters on impact damage of alumina-based ceramics. Journal of Materials Science. 1989; 24(7):2516-2532. http://dx.doi.org/10.1007/BF01174523.

7. Tasdemirci A, Tunusoglu G and Guden M. The effect of the interlayer on the ballistic performance of ceramic/composite armors: experimental and numerical study. International Journal of Impact Engineering. 2012; 44:1-9. http://dx.doi. org/10.1016/j.ijimpeng.2011.12.005.

8. Nunes LM, Paciornik S and d'Almeida JRM. Evaluation of the damage area of glass-fibre-reinforced epoxy-matrix composite materials submitted to ballistic impacts. Composites Science and Technology. 2004; 64(7-8):945-954. http://dx.doi.org/10.1016/ S0266-3538(03)00105-2.

9. Lee YS, Wetzel ED and Wagner NJ. The ballistic impact characteristic of Kevlar ${ }^{\circledR}$ woven fabrics impregnated with a colloidal shear thickening fluid. Journal of Materials Science. 2003; 38(13):2825-2833. http://dx.doi.org/10.1023/A:1024424200221.

10. Lee BL, Song JW and Ward JE. Failure of spectra polyethylene fibre-reinforced composites under ballistic impact loading. Journal of Composite Materials. 1994; 28(13):1202-1226. http://dx.doi.org/10.1177/002199839402801302.

11. Hine PJ, Duckett RA, Morye SS, Carr DJ and Ward IM. Modelling of the energy absorption. Composites Science and Technology. 2000; 60:2631-2642.

12. Meyers MA. Dynamic behavior of materials. New York: John Wiley \& Sons, Inc; 1994. p. 183-201. witness) than the aramid fabric with the additional advantages of being $4 \%$ lighter and $31 \%$ cheaper.

- In principle, both technical and economical reasons support the replacement of aramid fabric, as second layer backing the front ceramic in a mass, by giant bamboo reinforced epoxy composite, in which the natural fiber is also environmentally friendly.

\section{Acknowledgements}

The authors thank the support to this investigation by the Brazilian agencies: CNPq, CAPES and FAPERJ. It is also acknowledged the permission to the use of the SEM microscope by the PEMM from COPPE/UFRJ.

13. Abrate $\mathrm{S}$. Wave propagation in lightweight composite armor. Journal de Physique. IV. 2003; 110:657-662. http://dx.doi. org/10.1051/jp4:20020768.

14. Ulven C, Vaidya UK and Hosur MV. Effect of projectile shape during ballistic perforation of VARTM carbon/epoxy composite panels. Composite Structures. 2003; 61(1-2):143-150.

15. Hosur MV, Vaidya UK, Ulven C and Jeelani S. Performance of stitched /unstitched woven carbon/epoxy composites under high velocity impact loading. Composite Structures. 2004; 64(34):455-466. http://dx.doi.org/10.1016/j.compstruct.2003.09.046.

16. Monteiro SN, Lopes FPD, Barbosa AP, Bavitori AB, Silva ILA and Costa LL. Natural lignocellulosic fibers as engineering materials -An Overview. Metallurgical and Materials Transactions. A, Physical Metallurgy and Materials Science. 2011; 42(10):2963-2974. http://dx.doi.org/10.1007/s11661011-0789-6.

17. Satyanarayana KG, Sukumaran K, Mukherjee PS, Pavithran $\mathrm{C}$ and Pillai SGK. Natural fibre-polymer composites. Cement and Concrete Composites. 1990; 12(2):117-136. http://dx.doi. org/10.1016/0958-9465(90)90049-4.

18. Bledzki AK and Gassan J. Composites reinforced with cellulosebased fibers. Progress in Polymer Science. 1999; 24(2):221-274. http://dx.doi.org/10.1016/S0079-6700(98)00018-5.

19. Nabi Sahed D and Jog JP. Natural fiber polymer composites: a review. Advances in Polymer Technology. 1999; 18(4):351-363. http://dx.doi.org/10.1002/(SICI)1098-2329(199924)18:4<351::AIDADV6>3.0.CO;2-X.

20. Mohanty AK, Misra M and Hinrichsen G. Biofiber, biodegradable polymers and biocomposites: an overview. Macromolecular Materials and Engineering. 2000; 276-277(1):1-24. http:// dx.doi.org/10.1002/(SICI)1439-2054(20000301)276:1<1::AIDMAME1>3.0.CO;2-W.

21. Eichhorn SJ, Baillie CA, Zafeiropoulos N, Mwaikambo LY, Ansell MP, Dufresne A, et al. Review - current international research into cellulosic fibres and composites. Journal of Materials Science. 2001; 36(9):2107-2131. http://dx.doi. org/10.1023/A:1017512029696.

22. Mohanty AK, Misra M and Drzal LT. Sustainable bio-composites from renewable resources: opportunities and challenges in the green materials world. Journal of Polymers and the Environment. 2002; 10(1/2):19-26. http://dx.doi.org/10.1023/A:1021013921916.

23. Netravali AN and Chabba S. Composites get greener. Materials Today. 2003; 6(4):22-29. http://dx.doi.org/10.1016/S13697021(03)00427-9. 
24. Crocker J. Natural materials. Materials Technology. 2008; 23(3):174-178. http://dx.doi.org/10.1179/175355508X373378.

25. John MJ and Thomas S. Biofibers and biocomposites. Carbohydrate Polymers. 2008; 71(3):343-364. http://dx.doi. org/10.1016/j.carbpol.2007.05.040.

26. Satyanarayana KG, Arizaga GGC and Wypych F. Biodegradable composites based on lignocellulosic fibers - an overview. Progress in Polymer Science. 2009; 34(9):982-1021. http:// dx.doi.org/10.1016/j.progpolymsci.2008.12.002.

27. Monteiro SN, Lopes FPD, Ferreira AS and Nascimento DCO. Natural fiber polymer matrix composites: cheaper, tougher and environmentally friendly. JOM. 2009; 61(1):17-22. http:// dx.doi.org/10.1007/s11837-009-0004-z.

28. Faruk O, Bledzki AK, Fink HP and Sain M. Biocomposites reinforced with natural fibers: 2000-2010. Progress in Polymer Science. 2012; 37(11):1552-1596. http://dx.doi.org/10.1016/j. progpolymsci.2012.04.003.

29. Thakur VK, Thakur MK, Raghavan P and Kessler MR. Progress in green polymer composites from lignin for multifunctional applications: a review. ACS Sustainable Chemistry \& Engineering. 2014; 2(5):1072-1092. http://dx.doi.org/10.1021/sc500087z.

30. Holbery $\mathrm{J}$ and Houston D. Natural fiber reinforced polymer composites in automotive applications. JOM. 2006; 58(11):8086. http://dx.doi.org/10.1007/s11837-006-0234-2.

31. Njuguna J, Wambua P, Pielichowski K and Kayvantash K. Natural-fibre-reinforced polymer composites and nanocomposites for automotive applications. In: Kalia S, Kaith BS and Kaur I, editors. Cellulose fibers: bio-and nano-polymer composites. Berlin: Springer-Verlag; 2011. p. 661-700.

32. Lo TY, Cui HZ and Leung HC. The effect of fiber density on strength capacity of bamboo. Materials Letters. 2004; 58(21):25952598. http://dx.doi.org/10.1016/j.matlet.2004.03.029.

33. Chen X, Guo Q and Mi Y. Bamboo fiber reinforced polypropylene composites: a study of the mechanical properties. Journal of Applied Polymer Science. 1998; 69(10):1891-1899. http://dx.doi. org/10.1002/(SICI)1097-4628(19980906)69:10<1891::AIDAPP1>3.0.CO;2-9.

34. Shibata S, Cao Y and Fukumoto I. Flexural modulus of the unidirectional and random composites made from biodegradable resin and bamboo and kenaf fibres. Composites. Part A, Applied Science and Manufacturing. 2008; 39(4):640-646. http://dx.doi. org/10.1016/j.compositesa.2007.10.021.

35. Shin FG, Xian X-J, Zhena W-P and Yipp MW. Analysis of the mechanical properties and microstructure of bamboo epoxy composites. Journal of Materials Science. 1989; 24(10):34833490. http://dx.doi.org/10.1007/BF02385729.

36. Jain S, Kumar R and Jindal UC. Mechanical behavior of bamboo and bamboo composites. Journal of Materials Science. 1992; 27(17):4598-4604. http://dx.doi.org/10.1007/BF01165993.

37. Jain S, Jindal UC and Kumar R. Development and fracture mechanism of the bamboo/polyester resin composite. Journal of Materials Science Letters. 1993; 12(8):558-560.

38. Jain S and Kumar R. Processing of bamboo fiber reinforced plastics composites. Materials and Manufacturing Processes. 1994; 9(5):813-828. http://dx.doi.org/10.1080/10426919408934955.

39. Thwe MM and Liao K. Effects of environmental aging on the mechanical properties of bamboo glass fiber reinforced polymer matrix hybrid composites. Composites. Part A, Applied Science and Manufacturing. 2002; 33(1):43-52. http://dx.doi. org/10.1016/S1359-835X(01)00071-9.

40. Okubo K, Fujii T and Yamamoto Y. Development of bamboo based polymer composites and their mechanical properties.
Composites. Part A, Applied Science and Manufacturing. 2004; 35(3):377-383. http://dx.doi.org/10.1016/j.compositesa.2003.09.017.

41. Okubo K, Fujii T and Yamashita N. Improvement of interfacial adhesion in bamboo polymer composite enhanced with microfibrillated cellulose. JSME International Journal Series A Solid Mechanics and Material Engineering. 2005; 48(4):199-204. http://dx.doi.org/10.1299/jsmea.48.199.

42. Lee S-H and Wang S. Biodegradable polymer/bamboo fiber biocomposite with bio-based coupling agent. Composites. Part A, Applied Science and Manufacturing. 2006; 37(1):80-91. http://dx.doi.org/10.1016/j.compositesa.2005.04.015.

43. Huang $X$ and Netravali A. Biodegradable green composites made using bamboo micro/nano-fibrils and chemically modified soy protein resin. Composites Science and Technology. 2009; 69(78):1009-1015. http://dx.doi.org/10.1016/j.compscitech.2009.01.014.

44. Costa LL, Monteiro SN and Loiola RL. Mechanical behavior of polyester composites reinforced with continuous bamboo fibers. In: Proceedings of the Characterization of Minerals, Metals \& Materials - TMS Conference. 2010; Seattle, USA. Seattle; 2010. p. 1-6.

45. Ray AK, Mondal S, Das SK and Ramachandrarao PK. Bamboo - a functionally graded composite - correlation between microstructure and mechanical strength. Journal of Materials Science. 2005; 40(19):5249-5253. http://dx.doi.org/10.1007/ s10853-005-4419-9.

46. Martins LBS, Monteiro SN, Margem FM, Loiola RL, Pereira $\mathrm{AC}$ and Margem JI. Weibull analysis of the elastic modulus of bamboo fibers of the species Dendrocalamus giganteus. In: Hwang J-Y, Bai C, Carpenter JS, Ikhmayies S, Li B, Monteiro $\mathrm{SN}$, et al. editors. Characterization of minerals, metals \& materials 2013. Hoboken: John Wiley \& Sons; 2013. p. 441448.

47. Monteiro SN, Margem FM, Martins LBS, Loiola RL and Oliveira MP. Dynamic mechanical analysis of polyester composites reinforced with giant bamboo (Dendrocalamus giganteus) fiber. Materials Science Forum. 2014; 775-776:302-307. http:/ dx.doi.org/10.4028/www.scientific.net/MSF.775-776.302.

48. Monteiro SN, Margem FM, Martins LBS, Loiola RL and Oliveira MP. Tensile strength of polyester matrix composites reinforced with giant bamboo (Dendrocalamus giganteus) fibers. Materials Science Forum. 2014; 775-776:308-313. http:/ dx.doi.org/10.4028/www.scientific.net/MSF.775-776.308.

49. Martins LBS, Margem FM, Monteiro SN, Loiola RL and Margem JI. Izod impact test of polyester composites reinforced with bamboo fibers of the species Dendrocalamus giganteus. In: Hwang J-Y, Bai C, Carpenter JS, Ikhmayies S, Li B, Monteiro $\mathrm{SN}$, et al. editors. Characterization of minerals, metals \& materials 2014. Hoboken: John Wiley \& Sons; 2013. p. 581587.

50. Wambua P, Vangrimde B, Lomov S and Verpoest I. The response of natural fibre composites to ballistic impact by fragment simulating projectiles. Composite Structures. 2007; 77(2):232240. http://dx.doi.org/10.1016/j.compstruct.2005.07.006.

51. Monteiro SN, Lima ÉP, Louro LHL, Silva LC and Drelich JW. Unlocking function of aramid fibers in multilayered ballistic armor. Metallurgical and Materials Transactions. A, Physical Metallurgy and Materials Science. 2015; 46(1):37-40. http:// dx.doi.org/10.1007/s11661-014-2678-2.

52. Satyanarayana KG, Guimarães JL and Wypych F. Studies on lignocellulosic fibers of Brazil. Part I: sources, production, morphology, properties and applications. Composites Part A: Applied Science and Manufacturing. 2007; 38(7):1694-1709. http://dx.doi.org/10.1016/j.compositesa.2007.02.006. 